\title{
Obituary
}

\section{Dr. H. W. Dudley, O.B.E., F.R.S.}

$\mathrm{O}^{\mathrm{v}}$ October 3, nearly three weeks after a serious operation, Harold Ward Dudley died in a London nursing home. His death was a peculiarly tragic one, for until a month before it occurred his friends had no reason but to expect that there lay ahead many fruitful and happy years for him. That this was not to be is a most serious loss to biochemistry, creates a deplorable gap in the ranks of a wide circle of acquaintances, and is a cause of unfathomable grief to his family and to his intimate friends.

The eldest son of Florence and the late Rev. Joshua Dudley, he was born at Derby on October 30, 1887, and educated at Truro College, King Edward VI Grammar School, Morpeth, and the University of Leeds, where he specialised in chemistry. That his career was so uniformly successful was due to a combination of rare gifts with happy associations.

It was Dudley's good fortune while at Leeds to come under the influence of that inspiring trainer of biochemists, the late Prof. Julius B. Cohen, and further, after taking the degree of M.Sc. by a thesis on optical activity in menthyl esters, to obtain an 1851 Exhibition research scholarship. In the choice of Emil Fischer's laboratory as the place in which to work during the tenure of this scholarship he was again well advised, and there, under the immediate guidance of Prof. Wilhelm Traube, he carried out an investigation on the then topical subject of the purines, for which he received the Berlin $\mathrm{Ph} . \mathrm{D}$. in 1912.

There followed what was perhaps the most important step in Dudley's career when, on his return from Berlin, he became an assistant in the Herter Laboratory, New York; there he not only carried out important work under the guidance of another former Leeds student, H. D. Dakin, but what was more, formed a friendship which he treasured through. out the remainder of his life. It is needless to enumerate their publications, for their work is well known to biochemists and others whom it concerns, but one might mention 'glyoxalase', which they discovered, and 'protein racemisation' which they investigated, both of which are known to every student of biochemistry, as an indication of the fundamental nature of their researches.

Returning to Leeds in 1914, Dudley was for about a year lecturer in biochemistry, but soon the insistent voice of war called for the application of his high gifts in the service of his country, and he did not hesitate to respond. On the formation of an anti-gas research department under the leadership of Lieut.-Colonel E. H. Starling, at the Royal Army Medical College at Millbank, Dudley began work with the rank of Lieut. R.E. early in 1916, and was soon assisting in the evolution of the small box respirator, and in many other ways giving his fertile mind to problems of chemical warfare. Having by 1918 acquired a large experience of the subject, he was sent, with the rank of Major, in charge of a responsible anti-gas mission to the United States. He fulfilled these duties with characteristic care and thoroughness, and made many and varied new friends. He was awarded the O.B.F. for these war services.

After the War he returned, not without relief, to biochemistry, as head of the Department of Biochemistry of the Medical Research Committee (since Council), and worked at the Lister Institute until, in 1919, the Council obtained possession of its premises at Mount Vernon. There he worked until September 5 last, and formed a happy and fruitful association with the director, Sir Henry Dale, and with many other of his colleagues.

It was during these years that Dudley's best and most mature work was done. His work on the active principles of the posterior lobe of the pituitary body, although it fell short of his own expectations and high standards of achievement, was none the less a masterpiece of technique and a monument of patience. Then, after the discovery of insulin, by Banting and Best, he and Sir Henry Dale went to Toronto and established important contacts there on behalf of the Medical Research Council. Afterwards his fine flair for chemical methods was illustrated by the introduction by him of the picrate method for the extraction of insulin, and for its ready purification. After other important work on the subject of the preparation of insulin, he was entrusted with the preparation of the first international standard of that substance. The work, carried out in collaboration with others, on spermine, histamine and acetyl choline as tissue constituents also represented fundamental contributions to biochemistry, and are illustrations of his wide knowledge and abundant resource in investigation. He was elected a fellow of the Royal Society in 1930 .

Dudley's last research probably represented his most valuable contribution to knowledge, since it culminated in the discovery of the active alkaloid of ergot, called ergometrine. The last paper on this subject from his pen appeared in the Proceedings of the Royal Society on the day of his death. Although search had often been made for the constituent of ergot to which the contractions of the puerperal uterus which its administration occasions were due, it was shown by Moir that none of the hitherto known constituents of ergot was clinically responsible for this action. Dudley succe日ded, in collaboration with Moir, who carried out the clinical tests, in isolating this new alkaloid, which, thanks to him, is now "by far the most readily accessible alkaloid of ergot", and is already on the market.

The list of Dudley's great services to biochemistry would be incomplete without reference to his work for the Biochemical Society : he acted as secretary 
in 1922-24, and then became, jointly with Prof. Arthur Harden, an editor of the Biochemical Journal. In the performance of this arduous duty, which he continued for six years, it is true, as Boswell said of Johnson, that "That part of his labour which consisted in emendation and improvement of the pro. ductions of other contributors, like those employed in levelling ground, can be perceived only by those who had an opportunity of comparing the original with the altered copy". Certain it is that over this duty, and other editorial work as assistant editor of "British Chemical Abstracts", which he performed with equal care and thoroughness, he often worked far into the night, and over many of his week-ends. In 1921 he married Mary Nettleship, who, after prolonged illness, which was a source of the deepest sorrow to him, died as recently as last April. She was a great help to him in his editorial work, and those who heard her sing will long remember her beautiful voice.

Dudley was a keen fly fisher and of musical and artistic tastes. Though of a retiring disposition, he was always ready to place his wide knowledge at the service of others. He had a wide circle of friends and was a member of the Savage Club. Had he wished, he could have had many intimate friends, for his was a personality of rare charm. Those who were honoured with his close friendship will always treasure in their hearts the memory of his unselfish character, affectionate sympathy and characteristic placid wit, his patience in adversity and his intuitive penetration of all humbug. Our sympathy goes out especially to his mother, who had such good reason to be proud of him.

C.A. L. E.

\section{Prof. Rhoda Erdmann}

THE death of Prof. Rhoda Erdmann, of Berlin, has deprived the scientific world of a distinguished research worker and a most notable personality.

Dr. Erdmann began her scientific career as a protozoologist. Shortly before the War, she went to the United States, where she collaborated with Woodruff in protozoological studies which are now classical. When the United States entered the War, Dr. Erdmann, as a German subject, became the victim of war-time hysteria. She happened to be investigating an organism pathogenic to mice only, when a serious epidemic broke out in a neighbouring military camp. She was accused of having secretly infected the troops with the organism she was studying, and was arrested and imprisoned in New York. Her scientific and medical friends in the United States rallied to her aid and eventually she was acquitted of the fantastic charge.

After the War, Dr. Erdmann returned to Germany and began to work with tissue culture, mainly on problems connected with tumour growth. She was appointed a professor of the University of Berlin and placed in charge of the new Institut für Experimentelle Zellforschung at the Charité. She developed the institute until it became one of the principal centres for tissue culture research in Europe. At the same time she set herself to organise experi- mental cytology throughout the world. The Archiv für Experimentelle Zellforschung was founded in 1925 at her instigation, and was edited by her until her death. She also conceived the idea of an international society of. experimental cytology which should hold a triennial congress and of which the Archiv should be the official organ. This scheme she successfully accomplished, and thanks to her tireless efforts as general secretary three congresses have now been held, the third being at Cambridge in 1933 .

The change of government in Germany involved Dr. Erdmann in much hardship and difficulty, and in 1933 the institute to which she had devoted so much labour and care was closed, and she was pensioned. This was a great grief to her as she lived for her scientific work. She was accordingly delighted when in December 1934 the German Government decided to open another institute for experimental cytology under her directorship. Her health, which had troubled her for many years, was failing rapidly, but with undaunted courage and enterprise she began the task of creating her institute anew in a set of empty rooms in a private house. This task she was not destined to complete, and on August 23 she died at the age of sixty-four years.

Perhaps the quality which most endeared Dr. Erdmann to her friends was her gallant spirit. Oppressed by burdens of mind and body which many would have found overwhelming, she never lost heart but continued to work and plan for the future with the energy which characterised all she did. To those of us who knew her well, her death is a personal loss.

H. B. F.

Dr. HYNEK VYsoKÝ, professor of classical archæology in the Charles University, Prague, died at Rychnov, his birthplace in north-east Bohemia, on August 27, at the age of seventy-four years. $\mathrm{He}$ was educated at Prague and Berlin, and afterwards studied in Italy, Greece and Turkey. He wrote a number of Czech and German works on Greek archæology and mythology, and compiled most of the material dealing with archæology in Otto's (Czech) "Encyclopædia".

\section{We regret to announce the following deaths :}

Prof. Carl Barus, emeritus professor of physics in Brown University, Providence, R.I., known for his work on interferometry and acoustic pressures, on September 20, aged seventy-nine years.

Mr. F. Escombe, who collaborated with Mr. H. T. Brown in noteworthy investigations on photosynthesis, on October 12, aged sixty-three years.

Major-General A. W. Greely, known for his geographical work in the Arctic, aged ninety-one years.

Dr. Walter Hough, head curator of the Department of Anthropology in the U.S. National Museum, on September 20, aged seventy-six years.

Mr. Joseph A. Johnson, president of the American Institute of Electrical Engineers in 1934, on October 5 , aged fifty-three years. 